This is an electronic reprint of the original article. This reprint may differ from the original in pagination and typographic detail.

Author(s): Connal, Robert

Title: Velleius Paterculus: The Soldier and the Senator

Year: $\quad 2013$

Version:

Please cite the original version:

Connal, R. (2013). Velleius Paterculus: The Soldier and the Senator. The Classical

World, 107(1), 49-62. https://doi.org/10.1353/clw.2013.0108

All material supplied via JYX is protected by copyright and other intellectual property rights, and duplication or sale of all or part of any of the repository collections is not permitted, except that material may be duplicated by you for your research use or educational purposes in electronic or print form. You must obtain permission for any other use. Electronic or print copies may not be offered, whether for sale or otherwise to anyone who is not an authorised user. 


\title{
Velleius Paterculus: The Soldier and the Senator
}

\section{ROBERT T. CONNAL}

\begin{abstract}
Velleius Paterculus spent many years as soldier and senator before writing his brief history in honor of Marcus Vinicius. In this paper, I suggest that his history reveals tensions between the public attitudes of Velleius the senator and the opposing convictions of Velleius the former soldier. While the senator dutifully praises the peace brought about by Augustus and Tiberius, the soldier continues to distrust peace, and to consider war the proper business of a Roman. This leads Velleius to undermine his praise of Augustan and Tiberian virtues, when he finds them inappropriate to actual or potential foreign enemies.
\end{abstract}

Velleius Paterculus was a successful but not outstanding soldier whose subsequent career was apparently spent making no appreciable mark on the timid deliberations of the Tiberian senate. He avoided oblivion by the accidental survival, in a massively corrupt and subsequently lost manuscript, of a short historical work dedicated to his friend, Marcus Vinicius, on the eve of his consulate in A.D. 30. This Compendium has brought its author little praise. ${ }^{1}$ Macaulay considered Velleius a "vile flatterer" of Tiberius, capable of producing "sentences worthy of Tacitus" but mixing them with "an immense quantity of rant." ${ }^{2}$ Sir Ronald Syme thought him a liar and detested his memory. ${ }^{3}$ Even supporters of Velleius tend to see him as a follower of official lines, 
useful only as a contrast to Tacitus. ${ }^{4}$ In this paper, I suggest that the stated views of Velleius the senator on peace, war, and associated values are undermined by the lingering attitudes of Velleius the soldier. Velleius' work reveals internal tensions between, on the one hand, his wish to uphold the values and virtues of the Principate as they appeared to a Roman senator and, on the other hand, the deeply embedded attitudes that survived from his years of military service.

\section{Life and Career}

The tensions in Velleius' writing may be traced to the bipartite division of his adult life: essentially a period of military service followed by a rather longer period in the senate. There is no certain record of Velleius' life outside the pages of his Compendium, but the basic outline of his career is easily summarized from his own hints. It began with service as a military tribune in Thrace and Macedonia, around the turn of the millennium. He continued to serve as tribune under Augustus' grandson, Gaius Caesar, and from A.D. 4 to 6 as praefectus equitum in Germany under Tiberius. On his return to Rome, he was elected quaestor for A.D. 7, but a revolt in Pannonia and Dalmatia intervened and he returned to service as legatus Augusti, again under Tiberius. The Pannonians surrendered in A.D. 8, but the defeat of the Dalmatians the following year was followed by news of the loss, in Germany, of Quinctilius Varus and his three legions. Tiberius went to the Rhine, and Velleius followed. Both he and his brother, Magius Celer Velleianus, took part in Tiberius' delayed triumph in A.D. 12, and both brothers were advanced to the praetorship in A.D. 15, having been candidates before the death of Augustus. From then until A.D. 30, when he dedicated his Compendium to his friend and soon-to-be consul, Marcus Vinicius, Velleius must have spent his time largely in Rome. His senatorial career has left no record and perhaps deserved none. ${ }^{5}$ 
Prior to this conventional career, an equally conventional education may be surmised. Many of his acquaintances during his army career would have come from similar backgrounds: comfortable equestrian families who could afford to provide their sons with an education appropriate to their status. Though Velleius could claim senators, and probably even a Prefect of Egypt, among his relatives, ${ }^{6}$ his immediate background was equestrian and, like other equestrians, he would have studied as far as the rhetorical schools and gained, in the process, a fairly broad, if uncritical, acquaintance with Greek and Roman literature. Indeed, Velleius openly declares his dislike for criticism, adding after a note on the age of Pompey that he is making an observation non ut arguerem, sed ne arguerer ("not to criticize others but to avoid being criticized myself," Vell. Pat. 2.53.4). At a different time, and in different circumstances, he might have truly become only an ideal mirror of conventional or official attitudes, but he lived in a period of major change in the late aftermath of a long series of devastating civil wars, when at least implicit criticisms of both new and conventional ideas were difficult to avoid.

People as much involved in warfare as the Romans, and particularly in a period that had seen so much civil as well as foreign warfare, could hardly refrain from thinking about their experience and its meaning. Mary Beard, indeed, has suggested that it is precisely "warrior states that produce the most sophisticated critique of the militaristic values they uphold." ${ }^{, 7}$ During the terminal throes of the Republic that critique is most easily seen in Cicero, a successful though unenthusiastic general who thought it better to accept peace on any terms rather than endure a civil war (Cic. Fam. 6.4.4). With the coming of the Principate, the subject of territorial growth, taken for granted in the Republic, became a topic for discussion, on which varying opinions could be held. ${ }^{8}$ Roman writers were explicitly examining issues of war and peace and, having contemplated the long years of civil warfare, were looking forward to the possibilities of peace. 
For some, such as Vergil and Ovid, it seemed that the temple of Janus might become a prison in which war would ineffectually roar, or even a sanctuary in which peace could be protected. ${ }^{9}$ Even the Roman plebs could sometimes demonstrate against war. ${ }^{10}$

Given his enduring interest in literature, Velleius could hardly have avoided contact with new ways of handling attitudes and ideas, especially when they entered the mainstream through Maecenas' deft handling of patronage in support of Augustan propaganda. By the time he came to write his own history, Velleius had added to his existing familiarity with literature and military

leadership the experience of nearly twenty years spent in the senate. ${ }^{11}$ It was an excellent background for an ancient historian, and one that would have ensured a good grounding in the official attitudes that a determinedly uncritical historian ought to applaud. That he wished to applaud them is clear, and he was sometimes willing to hide or twist uncomfortable truths in order to do so. The senator, however, for all his experience in Rome, could never expunge either the memory of his military career or the attitudes that he had assimilated during those years. The evidence of his history, indeed, suggests that he remained proud of his military service and happy with at least some of its associated memories. For instance, he could still take pleasure in the peoples and places he had seen during his early years in the east (Vell. Pat. 2.101.3).

\section{Virtues of the Principate}

The differing views of Velleius the senator and Velleius the soldier appear clearly when Velleius deals with questions of peace and war and with the declared virtues of Augustus. The divine emperor made sure that his principal virtues would not be missed. After his death, his funeral monument announced them to an admiring public on two bronze columns fronting the entrance to his tomb, where Velleius may be expected to have read them. Augustus had ensured 
against error by writing the text himself. In it, he claimed four virtues in particular: virtus (valor), clementia (clemency), iustitia (justice), and pietas (piety) (RG 34). These were the virtues that the Senate and People of Rome had inscribed on a golden shield to be hung in the curia Iulia. Velleius was certainly familiar with this shield and its text; no senator could avoid it. This declaration of Augustus' virtues was distributed during his lifetime. A surviving copy at Arles, of Carreran marble, is dated to 26 B.C., only a year later than the original. ${ }^{12}$ Tiberius apparently thought that his valor could be taken for granted, but he repeated the virtues of clemency, justice, and piety on his coinage. Given the deliberate association of these virtues with both Augustus and Tiberius, Velleius could be expected to echo them dutifully in his Compendium. He tries hard, but the doubts of the old professional soldier are often discernible behind the attempts of the senator to commend virtues that it was advisable for him to commend.

Of those virtues, only virtus posed no serious problems for Velleius. It was a virtue of which he approved and which he had no reason to suspect either Augustus or Tiberius of lacking. Tiberius he had seen in action and Augustus too had a reputation for courage. Velleius could report how ingressus castra Lepidi, evitatis telis, quae iussu hominis pravissimi in eum iacta erant, cum lacerna eius perforata esset lancea, aquilam legionis rapere ausus est ("entering the camp of Lepidus and evading the weapons thrown at him on the orders of that vicious man, and with his cloak pierced by a lance, he courageously carried off the eagle of a legion."13 Courage was a quality that could hardly be altogether lacking in one who had made the dangerous journey from Octavian to Augustus. With the other virtues, Velleius faced double sources of difficulty: from his subjects and from his own earlier experiences.

In the case of iustitia, Velleius wrote early enough to be excused, albeit uneasily, for failing to see chinks in Tiberius' judicial armor. The founder of the Principate was a more 
difficult subject. The triumvirate of Octavian Antony, and Lepidus introduced proscriptions on such a scale that they might almost be construed as a low scale war waged by the rulers upon the ruled. They were an affront to iustitia, not only in the formal, legal sense, but also in the more informal sense of fairness. Velleius solved his problem, in part, by concentrating on Antony and Lepidus, both of whom were eager for revenge upon their enemies. When he came to Octavian whom Suetonius portrays as hardly a less enthusiastic supporter of political injustice (Suet. Aug. 27), Velleius passed over the matter even more quickly than his frequent emphasis on festinatio (haste) would have required: ${ }^{14}$ nihil tam indignum illo tempore fuit, quam quod aut Caesar aliquem proscribere coactus est aut ab ullo Cicero proscriptus est. ("Nothing at the time was more shameful than this: that Caesar should be made to proscribe anyone; that anyone should proscribe the name of Cicero!" Vell. Pat. 2.66.2). With minimal waste of words, he thus admitted Octavian's part in the proscriptions and excused him on the grounds that he was forced into it. This was no compliment to Octavian's moral courage, and Velleius passed over the matter as quickly as public knowledge of the proscriptions would allow. Having done so, he could turn his attention to the more congenial task of castigating Antony, especially for the killing of Cicero, a crime that Octavian had wished to prevent.

Beyond this difficulty with his subject matter, Velleius faced another difficulty with his own attitudes. As long as his topic lay within the confines of Rome, or at least of Italy, Velleius the senator could gloss over the injustices of Octavian not because Velleius doubted the value of justice but because the historical facts were embarrassing. Once he moved outside Italy, however, the experience of the soldier made it impossible for Velleius to hide a suspicion that justice could be irrelevant or worse when dealing with people who had been, and might again be, enemies of Rome. He was particularly critical of Varus, who, Velleius thought, saw himself more as an 
urban praetor in the Roman forum than a general leading Roman troops in Germany and could thus be deliberately misled by a series of bogus cases, a kind of judicial camouflage behind which the German leader Arminius could prepare a devastating attack (Vell. Pat. 2.118.1-3). If not earlier, then certainly after the destruction of Varus and his legions, Velleius came to believe, if only on practical grounds, that military action should often take precedence over formal justice.

Clemency posed similar problems. Augustus claimed that he regularly spared citizens who had fought against him and that he preferred to preserve rather than destroy the foreign nations against which his external wars were fought $(R G 3)$. Velleius, the faithful senator, was duly insistent in his portrayal of Augustan clemency, but it was not an easy task. Clemency was a latecomer among the proclaimed virtues of Augustus (Seneca [Cl. 1.11] thought it merely the exhaustion of cruelty) and there were some difficult topics to handle or avoid. The proscriptions gave little room for claims of clemency and Velleius had every reason to leave them behind as quickly as possible. He was, however, happy to report that after his victory at Actium, Octavian was almost universally clement and only a few lost lives for which they refused to plead. ${ }^{15}$ Similar clemency was shown after the victory at Alexandria, where fuitque et fortuna et clementia Caesaris dignum, quod nemo ex iis, qui contra eum arma tulerant, ab eo iussuve eius interemptus est ("it was worthy of the fortune and clemency of Caesar that none of those who had taken arms against him was killed either by him or on his orders," Vell. Pat. 2.87.2). Velleius himself, however, immediately throws doubt on the latter claim, when he reports the reluctant suicide of the terrified Canidius. ${ }^{16}$

Velleius' efforts to portray the clemency of Octavian whether accurately or otherwise, demonstrate that the senator publicly favored that virtue and approved of its application at least in wars fought between Romans. Velleius the soldier may have been less troubled about clemency, 
a virtue that he seldom extols. The term clementia occurs infrequently in his text and it is hardly accidental that the recipients of clemency are almost invariably Roman. ${ }^{17}$ The one exception to the rule is Carthage, a city that Scipio Aemilianus made suae virtutis monimentum, quod fuerat avi eius clementiae ("a monument to his valor, as it had once been to his grandfather's clemency,"Vell. Pat. 1.12.5). Velleius had evidently absorbed the literary convention that the defeat of Carthage, by removing Rome's most dangerous enemy, had led to a decline in Rome's military character, so that the Roman state passed in somnum a vigiliis, ab armis ad voluptates, $a$ negotiis in otium ("from wakefulness to slumber, arms to pleasure, and action to relaxation," Vell. Pat. 2.1.1). A few chapters later, however, he apparently forgot this regret and congratulated Scipio that no man before him clariore urbium excidio nomen suum perpetuae commendavit memoriae ("perpetuated his name by a more glorious destruction of cities," Vell. Pat. 2.4.3). Against barbarian foes, clementia was hardly considered. On professional grounds, Velleius approved of harsher methods: of heavy losses in enemy lives (Vell. Pat. 2.98.2), and of the destruction of fields, houses and people (Vell. Pat. 2.115.2). In his description of the Varian disaster he notes how the enemy forces were people whom the Romans semper more pecudum trucidaverat ("had always slaughtered like cattle," Vell. Pat. 2.119.2), a situation of which he evidently approved. What Velleius favored, however, was not cruelty or savagery, the true opposites of clementia, but the stern or even unlimited prosecution of war. Other considerations apart, ambitious Roman commanders needed dead enemies. A triumph required the killing of at least 5,000 of the enemy in a single battle,${ }^{18}$ and the tendency to exaggerate the enemy's losses was at least theoretically limited by law: a Lex Maria Porcia forbade either the exaggeration of enemy losses or the concealment of Roman ones. Overindulgence in clemency would spoil the body count. 
Piety, or the appearance of piety, played a significant part in Augustus' portrayal of himself, reflecting a belief that the people he ruled would respond well to claims of piety, a virtue that emphasized his importance to the country as well as to its gods. ${ }^{19}$ Augustus made religious piety an element in his accumulation of power and influence by gathering priesthoods. To the offices of pontifex maximus and augur, he added membership in several other priesthoods including the Arval Brethren and the fetials. It was as leader of the fetials that he had declared war against Cleopatra in 32 B.C. using the plausibly ancient ritual of the priesthood. ${ }^{20}$ Given this very public display of priestly and military piety, Velleius might be expected, as dutiful purveyor of the official line, to give adequate space to the subject, but he seldom mentions priesthoods, and when he does it is usually only as evidence of social distinction, deserved or undeserved. ${ }^{21}$

\section{Problems of Peace}

Velleius ends his book with a possibly sincere prayer for peace: custodite, servate, protegite hunc statum, hanc pacem, hunc principem ("guard, maintain, and protect our present condition, peace, and emperor," Vell. Pat. 2.131.1). Velleius, however, realizes that the gods might accept peace at the cost of war and one of the gods to whom his prayer is addressed is Mars Gradivus, a marching, soldier's Mars. Indeed, the form of peace most acceptable to the Roman mind was victorious peace and Augustus was careful to note that the senate voted for the Ara Pacis, the altar of Augustan peace, after successful action in Spain and Gaul (RG 12). The gift of peace was given, not received, by Rome, ${ }^{22}$ and Velleius' prayer should be seen in this context. If Rome was enjoying a condition of relative peace under Tiberius, it was largely because Tiberius had fought so many of the wars and battles that produced it; and behind Tiberius were soldiers like Velleius by whose services peace by victory was achieved. 
It is in this matter of peace, however, where Velleius the soldier parts most drastically from the official line. In one of the most important items of official propaganda, Velleius demonstrates a view diametrically opposed to the intended message. Augustus was clear about the importance of the repeated closure of the temple of Janus during his reign.

Ianum Quirinum, quem claussum esse maiores nostri voluerunt, cum per totum imperium populi Romani terra marique esset parta victoriis pax, cum prius, quam nascerer, a condita urbe bis omnino clausum fuisse prodatur memoriae, ter me principe senatus claudendum esse censuit. ${ }^{23}$

The temple of Janus Quirinus, which our ancestors wished to have closed only when peace was assured by victory on land and sea throughout the empire of the Roman people, is said to have been closed only twice before my birth since the city was founded; during my principate, the senate three times ordered its closure.

Victorious peace had been achieved with remarkable frequency during Augustus' reign. The closing of the temple doors proved the point, which the dedication of the Ara Pacis further emphasized. In a society blindly enamored with war, neither the closing of Janus' doors nor the building of the Ara Pacis would have served the propaganda with which the emperor had been so much concerned. But here is Velleius on the same topic: 
Immane bellicae civitatis argumentum, quod semel sub regibus, iterum hoc T. Manlio consule, tertio Augusto principe certae pacis argumentum Ianus geminus clausus dedit. (Vell. Pat. 2.38.3)

The warlike character of our nation is clearly shown by the temple of Janus, which has been closed only three times as a sign of absolute peace: first under the kings, then in the consulship of Titus Manlius, and a third time during the reign of Augustus.

Velleius cares not a fig that the closed doors denote peace. He cares about the centuries during which the doors stood open. He even reduces the three closures claimed by Augustus into a single event. Perhaps the oversight was accidental, but it is suggestive whatever its cause. At first, it might seem to suggest simply that the prayer for peace at the end of Velleius' book is a piece of arrant hypocrisy after all. Velleius himself offers a different solution: that however much he might sometimes hope for peace, he could not quite bring himself to believe in it.

Peace, for Velleius, could be a dangerous condition that sapped the Roman character while having, paradoxically, the opposite effect on some of Rome's enemies. While peace spoiled the nerve of the Roman people and led to luxury and a loss of martial character, peace among the enemies of Rome allowed them to strengthen themselves for renewed warfare. The Pannonian revolt of A.D. 6 was sufficiently serious to have Augustus claim in the senate-albeit exaggeratedly—that the enemy might reach Rome in ten days (Vell. Pat. 2.111.1). Velleius knew what to blame. All of Pannonia had taken to arms because the Pannonians were insolens longae pacis bonis ("made insolent by the advantages of a long peace,"Vell. Pat. 2.110.2). A few chapters later, Velleius shows Marcus Lepidus leading an army per gentis integras immunesque 
adhuc clade belli et eo feroces ac truces ("through peoples as yet unharmed and undisturbed by the devastation of war and therefore still fierce and savage," Vell. Pat. 2.115.2). These dangers were surmounted, but Velleius clearly retained an impression that peace among seemingly conquered peoples was at best an uncertain quality.

He was probably right. Supposedly peaceful civil areas in Britain and Gaul, for example, were still garrisoned long after their conquest. There was a garrison stationed at Gloucester into the second century, and the fort of Mirebeau was built in Gaul as late as the Flavian period, with space for a full legion. It evidently took some time before the conquered gave up resistance in favor of the steady development of a culture that incorporated all the diverse elements of the empire. ${ }^{24}$ Velleius, perhaps inadvertently, suggests one reason for instability in Gaul when he boasts, as a measure of Caesar's success, that Gaul sent almost as much to Rome as the rest of the world together (Vell. Pat. 2.39.1). Even allowing for exaggeration on Velleius' part, the amount involved must have been substantial. Drinkwater has shown how Gallic coins, after the conquest, were mostly of silver and bronze, since their gold had gone to the enrichment of Romans. ${ }^{25}$ Whatever else it might be, peace was seldom absolute, and Velleius was aware of this. After all, of Rome and Carthage he thought that per annos centum et viginti aut bellum inter eos populos aut belli praeparatio aut infida pax fuit ("for a hundred and twenty years relations between those peoples consisted of war, preparations for war, or treacherous peace," Vell. Pat. 1.12.6). Peace, for Velleius, probably tended to seem always treacherous. It was a view that could only have been strengthened by the Varian disaster of A.D. 9 .

Varus made the poor general's fundamental error of underestimating the enemy. Velleius believed that Varus saw the Germans as a people who, though they could not be made subservient by violence, might nonetheless be appeased by law (Vell. Pat. 2.117.3). Velleius is 
clear about the basic problem: he claims that Varus went into Germany velut inter viros pacis gaudentes dulcedine ("as though among people rejoicing in the sweetness of peace," Vell. Pat. 2.117.4), when in fact they were merely making use of peace as a tool with which to prepare for the destruction of Varus and his troops. With the benefit of hindsight, Velleius sees this as obvious pretense, though Varus had some solid reasons for believing as he did. Germany beyond the Rhine gave the appearance of developing Roman habits and accepting a Romanized way of life. Dio's claim that cities were being founded and that the inhabitants were becoming used to markets and peaceful assemblies (Dio 56.18) is borne out by the excavated site of Waldgirmes, in Hessen. ${ }^{26}$ Varus, however, seems to have seriously overestimated Roman progress. Velleius was speaking of a time only a few years earlier when he congratulated Tiberius on the good fortune and planning that allowed him to organize a junction of fleet and army on the Elbe ${ }^{27}$ a not unrealistic indication of the relatively unknown area in which the army and navy had to operate. Whittaker has suggested that travelling across country with the help of a Roman itinerary could be compared to navigating around London with no other aid than a map of the Underground. ${ }^{28}$ It is likely to be significant that, speaking of the year after the Varian disaster, Velleius notes how Tiberius' advance included the creation of new roads, as well as the application of violence. ${ }^{29}$ Besides its military value, it could be a way of reducing the area's continuing uncertainties. ${ }^{30}$ Velleius was perhaps thinking of frontier geography as well as Varus' personal limitations when he complained that Varus behaved like a city praetor in Rome instead of acting like a general among enemies (Vell. Pat. 2.118.1).

IV. Conclusion: Velleius on Peace and War Velleius cannot be considered an astute, deliberate critic of Roman attitudes, but neither can he avoid revealing traces of doubt behind his attempts to support an official view which he must 
have learned during his senatorial career. Years of military experience had developed views on peace, war, and related values that were not easily dismissed even as they fell out of step with the developing propaganda of the Principate. If he had ever believed in justice and clemency, life on the uncertain edge of Augustan peace had persuaded Velleius that those virtues were of limited value in the practical life of a frontier soldier. Velleius possessed pietas, especially of the kind directed towards the state he served, but his piety could not hide a conviction that it was primarily his own efforts and those of his colleagues that achieved the ideal of peace by victory. Also, though he might approve of peace in theory, and even in practice, it was a condition that he could never bring himself entirely to trust. Peace was not always easily distinguishable from war and neither condition could be regarded as absolute. The Empire normally presented a patchwork of relative peace and varying intensities of war, interspersed with regions of banditry and shifting levels of ordinary, often violent, crime; and all this was held within frontiers both mobile and indistinct. While warming a senator's seat in Rome, Velleius could try to believe in a world made safe and secure by Augustan peace, but in the back of his military mind there lay an unalterable conviction that Rome was at its best in war and too easily weakened by peace, which in turn only encouraged fresh attacks from Rome's enemies. The temple of Janus, far from imprisoning war or protecting peace, as Vergil and Ovid wished to believe, was put to better use when its gates lay comfortably open and war was free, when the need arose, to go about its proper Roman business.

University of Jyväskylä robert.t.connal@jyu.fi 
${ }^{1}$ Compendium is a convenient, though imperfect, title. The Loeb Velleius uses Compendium of Roman History but Velleius' book, in its original form, was too wide-ranging to be considered a purely Roman history. See R. J. Starr, “The Scope and Genre of Velleius' History,” CQ 31 (1981) 162-174. The original title has not survived; for a discussion of alternatives, see A. J. Woodman, Velleius Paterculus: The Tiberian Narrative (2.94-131) (Cambridge 1977) 95. The edition used is Loeb 152 (1961), by Frederick W. Shipley. All translations are by the author.

${ }^{2}$ G. O. Trevelyan, The Life and Letters of Lord Macaulay (London 1876) 468. Macaulay's comments were recorded at the end of his copy of Velleius, which he seemingly read at least twice: in June 1835 and again in May 1836.

${ }^{3}$ For specific instances of suspected Velleian untruths see R. Syme, "Mendacity in Velleius," AJPh 99 (1978) 45-63. For a more sympathetic treatment of Velleius see G. V. Sumner, "The Truth about Velleius Paterculus: Prolegomena," HSPh 74 (1970) 257-297.

${ }^{4}$ See e.g. B. Levick, Tiberius the Politician (London and New York 1999) xi.

${ }^{5}$ There is a good account of Velleius' known and conjectured civil and military positions in Sumner (above, n.3). There may have been military employments following his entry to the senate, but Velleius himself provides no information later than A.D. 15.

${ }^{6}$ There is a useful discussion in Sumner (above, n.3).

${ }^{7}$ M. Beard, The Roman Triumph (Cambridge, Mass., and London 2009) 4.

${ }^{8}$ G. Woolf, "Roman Peace," in J. Rich and G. Shipley, eds., War and Society in the Roman World (London 1993) 171-194. 
${ }^{9}$ J. B. de Brohun, "The Gates of War (and Peace): Roman Literary Perspectives," in K. A. Raaflaub, ed., War and Peace in the Ancient World (Oxford 2007) 256-278. The image of the temple of Janus as prison is from Verg. Aen. 286-296, and that of sanctuary for peace from Ov. Fast. 279-282.

${ }^{10}$ T. W. Africa, "Urban Violence in Imperial Rome," Journal of Interdisciplinary History 2 (1971) 3-21. In practice, riots against war might be due to the negative effects of war on the plebs themselves, especially if the grain ships were delayed; but the criticism existed. The plebs would not accept war at any price. E. O'Gorman ("Imperial History and Biography at Rome," in A. Feldherr and G. Hardy, eds., The Oxford History of Historical Writing, [Oxford 2011] 297) finds Velleius similarly practical, rather than idealistic, on the subject of peace.

${ }^{11}$ Owing to the extension of his military service, Velleius could have spent little time in the senate before A.D. 12 .

${ }^{12}$ A fragment from a similar marble copy was found in Augustus' mausoleum, and the shield occurs also on Augustan coinage. For a detailed consideration of its repeated occurrence, see A. E. Cooley, Res Gestae Divi Augusti: Text, Translation and Commentary (Cambridge 2009) 266269. This list of virtues was intended to be public and was an important and lasting element in Augustus' portrayal of himself; it appeared within a few years of Actium and survived beyond his death in A.D. 14.

${ }^{13}$ Vell. Pat. 2.80.3. For similar examples of courage, see also Suet. Aug. 8.1, 10.4.

${ }^{14}$ On festinatio, see J. A. Lobur, "Festinatio (Haste), Brevitas (Concision), and the Generation of Imperial Ideology in Velleius Paterculus," TAPA 137 (2007) 211-230. 
${ }^{15}$ Vell. Pat. 2.86.2. See A. J. Woodman, Velleius Paterculus: The Caesarian and Augustan Narrative (2.41-93) (Cambridge 2004) 230 in support of Velleius' inclusion of executions at this point, and a discussion of alternative emendations.

${ }^{16}$ Vell. Pat. 2.87.3. Syme, however, (above, n.3) 51, suggests that Velleius' text need not necessarily imply suicide. The death of Canidius comes at the end of a series of suicides (following Brutus, Cassius, Antony, and Cleopatra), which implies—-but does not definitely claim - a similar death. He could have been executed. See J. A. Lobur, Consensus, Concordia, and the Formation of Roman Imperial Ideology (New York 2008) 123, for the view that Velleius was led astray by his interest in suicide. Dio (51.2.5-6) claims that a number of knights and senators were killed.

${ }^{17}$ Vell. Pat. $2.55 .2 ; 2.57 .1 ; 2.69 .6 ; 2.83 .2 ; 2.86 .2 ; 2.87 .2 ; 2.100 .4$

${ }^{18}$ Val. Max. 2.8.1. The precision of the figure may be fanciful, but generals did not gain their triumphs by kindness.

${ }^{19}$ The text of the golden shield, as preserved on the Arles marble copy (AE 1994, 27), emphasises the connection of pietas in particular with both gods and country (DEOS PATRIAMQVE). Piety could take other forms, but here the emphasis is on public virtues, essentially national and religious.

${ }^{20}$ See e.g. T. E. J. Wiedemann, “The Fetiales: A Reconsideration,” CQ 36.2 (1986) 478-490 for doubts. The antiquity or otherwise of the ritual is not at issue here. The declaration of war against Cleopatra demonstrates the use of the fetial priesthood — and by extension of Octavian's real or assumed piety — as part of a propaganda exercise aimed at moulding public opinion towards the 
struggle with Antony. On this, see also M. Reinhold, "The Declaration of War against Cleopatra," CJ 77.2 (1982) 97-103.

${ }^{21}$ See e.g. Vell. Pat. 2.3.1, 2.43.3, 2.63.1. For the likelihood that Romans seldom allowed religious feeling to interfere in war, see M. D. Goodman and A. J. Holladay, "Religious Scruples in Ancient Warfare," CQ 36 (1986) 151-171. Seen in this light, Velleius' limited interest is perhaps not uncommon for someone with his military background.

${ }^{22}$ C. A. Barton, “The Price of Peace in Ancient Rome,” in Raaflaub (above, n.9) 245-255.

${ }^{23} R G$ 13. I quote the Loeb edition of Frederick W. Shipley (1961). There is a useful discussion of the three closures under Augustus in Cooley (above, n.13) 159-160.

${ }^{24}$ On the creation of a new imperial culture, rather than conflict between Roman and native cultures, see G. Woolf, “Beyond Romans and Natives,” World Archaeology 28.3 (1997) 339_ 350.

25 J. F. Drinkwater, Roman Gaul: The Three Provinces, 58 B.C.-A.D. 260 (London 1984) 119.

${ }^{26}$ Though surrounded by a seemingly military double ditch, the interior was of a markedly civilian character and included a forum that had once contained a life-sized gilded equestrian statue, probably of Augustus. See S. Von Schnurbein, “Augustus in Germania and His New ‘Town' at Waldgirmes East of the Rhine,’ JRA 16 (2003) 93-107.

${ }^{27}$ Vell. Pat. 2.106.2-3. Velleius had reason to be impressed by his commander's achievement. See Woodman (above, n.1) 144-146. 
${ }^{28}$ C. R. Whittaker, Rome and Its Frontiers: The Dynamics of Empire (London and New York 2004) 77.

${ }^{29}$ Vell. Pat. 2.120.2. But see Woodman (above, n.1) 207 for the possibility that Velleius meant rather that Tiberius crossed the frontier. For a later discussion of roads and frontiers, and some problems of nomenclature, see B. Isaac, "The Meaning of the Terms Limes and Limitanei," JRS 78 (1988) 125-147.

${ }^{30}$ On the related uncertainties of administrative, physical and mental boundaries, see A. Lintott, “What Was the 'Imperium Romanum'?” G\&R 28 (1981) 53-67. Also useful is D. Potter, “Empty Areas and Roman Frontier Policy," AJPh 113 (1992) 269-274, which discusses the control of unoccupied areas extending several miles beyond the frontier. 